\title{
A 40-year evaluation of drivers of African rainforest change
}

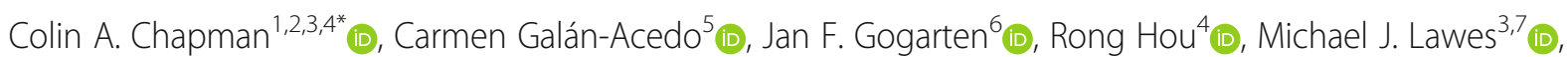
Patrick A. Omeja ${ }^{8}$, Dipto Sarkar ${ }^{9}$ (D, Anna Sugiyama ${ }^{10}$ and Urs Kalbitzer ${ }^{11,12}$ (B)

\begin{abstract}
Background: Tropical forests are repositories of much of the world's biodiversity and are critical for mitigation of climate change. Yet, the drivers of forest dynamics are poorly understood. This is in large part due to the lack of long-term data on forest change and changes in drivers.
\end{abstract}

Methodology: We quantify changes in tree abundance, diversity, and stand structure along transects first enumerated in 1978 and resampled 2019 in Kibale National Park, Uganda. We tested five predictions. First, based on the purported role of seed dispersal and herbivory and our quantification of changes in the abundance of frugivores and herbivores, we tested two predictions of how faunal change could have influenced forest composition. Second, based on an evaluation of life history strategies, we tested two predictions concerning how the forest could have changed following disturbance that happened prior to written history. Finally, based on a 50year climate record, we evaluate the possible influence of climate change on forest dynamics.

Results: More trees were present on the assessed transects in 2019 (508) than in 1978 (436), species richness remained similar, but diversity declined as the number of dominant species increased. Rainfall increased by only 3 $\mathrm{mm}$ over the 50 years but this had not significant effect on forest changes measured here. Annual average monthly maximum temperature increased significantly by $1.05^{\circ} \mathrm{C}$ over 50 years. The abundance of frugivorous and folivorous primates and elephants increased over the 50 years of monitoring. Neither the prediction that an increase in abundance of seed dispersing frugivores increases the abundance of their preferred fruiting tree species, nor that as an increase in folivore abundance causes a decline in their preferred species were supported. As predicted, light-demanding species decreased in abundance while shade-tolerant species increased as expected from Kibale being disturbed prior to historical records. Finally, while temperature increased over the 50 years, we found no means to predict a priori how individual species would respond.

Conclusions: Our study revealed subtle changes in the tree community over 40 years, sizable increases in primate numbers, a substantial increase in the elephant population and an increase in local temperature. Yet, a clear picture of what set of interactions impact the change in the tree community remains elusive. Our data on tree life-history strategies and frugivore/herbivore foraging preferences suggest that trees species are under opposing pressures.

Keywords: Climate change, Elephants, Succession, Primates, Disturbance, Forest regeneration

\footnotetext{
* Correspondence: colin.chapman.research@gmail.com

'Department of Anthropology, Center for the Advanced Study of Human

Paleobiology, The George Washington University, 20037 Washington, DC, USA

Wilson Center, 1300 Pennsylvania Avenue NW, 20004 Washington, DC, USA

Full list of author information is available at the end of the article
}

\section{Springer Open}

( ) The Author(s). 2021 Open Access This article is licensed under a Creative Commons Attribution 4.0 International License, which permits use, sharing, adaptation, distribution and reproduction in any medium or format, as long as you give appropriate credit to the original author(s) and the source, provide a link to the Creative Commons licence, and indicate if changes were made. The images or other third party material in this article are included in the article's Creative Commons licence, unless indicated otherwise in a credit line to the material. If material is not included in the article's Creative Commons licence and your intended use is not permitted by statutory regulation or exceeds the permitted use, you will need to obtain permission directly from the copyright holder. To view a copy of this licence, visit http://creativecommons.org/licenses/by/4.0/. 


\section{Introduction}

Tropical forests are repositories of much of the world's biodiversity. Covering only $7 \%$ of the world's land surface, tropical forests account for $60 \%$ of the world's biodiversity (Bradshaw et al. 2009). These forests are also critical to successful mitigation of climate change. For example, tropical forests and wetlands are estimated to contribute $23 \%$ of the mitigation needed to limit global warming to $2^{\circ} \mathrm{C}$ by 2030 (Griscom et al. 2017; Wolosin and Harris 2018). Yet, these forests are increasingly threatened. While there is considerable controversy surrounding the magnitude of the loss of tropical forest, it is estimated that globally, $\sim 60$ million ha of tropical primary forest were lost from 2002 to 2019, with most forest loss occurring in Brazil (24.5 Mha), Indonesia (9.5 Mha), and the Democratic Republic of the Congo (4.8 Mha) (Weisse and Gladman 2020). To put this in perspective, an area of old-growth tropical forest larger than Madagascar was lost over 18 years. The tree cover loss reported here is defined is the removal of tree canopy by human or natural causes, including fire, but does not consider tree restoration and is thus not an indication of net change; however, sadly most areas have been converted from forest to agricultural fields. Given the extent of loss, restoring tropical forest is a necessary part of mitigating the effects of climate change, regaining many ecological services, and will be needed to prevent mass extinctions. This will require an understanding of what naturally drives tropical forest dynamics and the ecological processes that are affected (Ma et al. 2016).

Surprisingly, the drivers of forest dynamics are poorly understood, due in large part to the lack of suitable long-term data spanning decades. Many of the species involved in structuring tropical forest ecosystems have generation times from years to many decades and even hundreds of years (trees Swaine, Lieberman and Putz 1987; birds, Sæther et al. 2005; mammals, Clutton-Brock and Sheldon 2010). Their populations typically respond very slowly to most environmental changes that are anything short of catastrophes (Chapman et al. 2013a; Jezkova and Wiens 2016).

Further complicating our understanding of the drivers of tropical forest dynamics is the need to consider the synergistic interaction of multiple drivers. Important interacting processes include pollination, seed dispersal and predation, herbivory, disease, competition, disturbance regimes, and climate. All of these are dynamic in nature and are effected by human actions, consequently the legacy effect of human imposed disturbance that occurred decades or centuries earlier has to be considered (Richards 1996). Furthermore, normative ecosystem response is obscured by stochastic events like droughts (Condit et al. 2017). Thus, it is hardly surprising that our understanding of driving factors/processes has often been judged by examining the strong signal produced by extreme events. For example, Harrison et al. (2013) provided detailed tree census data 15 years after intensive hunting eliminated most large frugivores. They documented a consistent decline in tree diversity but found no evidence of reduction in above-ground biomass (see also Chapman et al. 2003; Poulsen et al. 2013). Their study clearly illustrates the importance of frugivores in maintaining tree diversity but does not contribute to an understanding of the relative importance of drivers of forest composition under less extreme conditions.

Here, we quantify changes in tree abundance, diversity, and stand structure (species rank abundance, and size class structure) and mammal abundance of ten species in Kibale National Park, Uganda (hereafter Kibale) between 1978 and 2019. We consider five predictions of how the forest community could have been affected over 23-50 years. We make no assumptions about the relative importance of one driver of change over another, we simply determine if an effect can be detected. We recognize that the forest ecosystem is naturally dynamic and change will be occurring through many natural processes.

Mounting evidence suggests bottom-up processes, like seed dispersal and herbivory, can be dominant drivers of tropical forest communities (Crawley 1989; Wright and Jones 2006; Wright et al. 2007; Chapman et al. 2013a). For example, a reduction in populations of large-bodied seed-dispersing primates corresponds with lower seedling densities of large-seeded forest trees species (Chapman and Onderdonk 1998; Pacheco and Simonetti 2000) and higher seedling aggregations around parent trees (Pacheco and Simonetti 2000). Similarly, by foraging on trees, elephants (Loxodonta africana) can convert forest ecosystems to grasslands (Laws 1970; Stuart et al. 1985; Dublin et al. 1990; Wright and Jones 2006). Folivorous primates can also shift tree community structure by eating leaves of preferred species to the extent that the trees die, or by eating flowers to the degree that species cannot set fruit (Hladik 1977; Chapman 1995; Jin-Eong 1995; Chapman et al. 2013a; Chapman et al. 2013b). Based on the purported role of seed dispersal and herbivory in structuring tropical forests, we advance two predictions. First, an increase in the abundance of seed dispersing frugivores, in relation to all seed dispersal agents, is expected to correspond to an increase in the abundance of fruit bearing trees prominent in their diet and vice versa (Prediction 1). Second, increases in arboreal herbivore/folivore abundance is expected to correspond to a decrease in the abundance of their preferred foods (Prediction 2).

Research since the $1980 \mathrm{~s}$ has shown that many forests traditionally considered "pristine" were disturbed by people (i.e., between 100 and 4000 years ago, Clark 
1996). For example, the first paleoecological studies from the Darien of Panama, an area previously described as one of the last "untouched" Neotropical forests, revealed an extensive 4000 year old history of human disturbance (Bush and Colinvaux 1994). Similar evidence has accumulated for many other regions, including Africa, Central America, and Amazonia (Gomez-Pompa 1987; Tutin and Oslisly 1995; Richards 1996; Bush et al. 2007). Disturbance influences what resource allocation (Grubb 1977; Bloor and Grubb 2003; Zanne and Chapman 2005; Zanne et al. 2005; Kitajima and Poorter 2008) and recruitment strategies of trees (Coley 1983; Hubbell et al. 1999; Dalling et al. 2012) are most adapted for a particular location and time following disturbance. For example, light-demanding species are better adapted to recruit in gaps following disturbances and use new resources for growth, while shade-tolerant species tend to recruit into the system slowly over decades and invest more in their wood density, roots, and defensive mechanisms (e.g., plant toxins) so that they are not disrupted by herbivory during their establishment (Grubb 1977; Richards 1996; Wright 2002; Chave et al. 2009). In addition, some species are adapted to recruit after catastrophic disturbances that create extremely large clearings and these large clearings can be made naturally or through human actions (Chazdon 2003). For example, mahogany (Swietenia macrophylla) recruits in areas dramatically disturbed by hurricanes (Snook 1996) or in areas of erosion or in forests killed by flooding (Gullison et al. 1996). With respect to Kibale, the rainforest was disturbed by people prior to written or oral history, thus we make the following predictions. First, we predict that light-demanding species should decrease in abundance between 1978 and 2019, while shade tolerant species increase (Prediction 3). Second, tree species that recruit in areas typically disturbed by human clearance (i.e., larger than a single tree fall gap) should decline in abundance over the 40 years (Prediction 4).

Plants respond to slight shifts in temperature and rainfall associated with climate change (van Vliet and Schwartz 2002; Walther et al. 2002). For example, the average first flowering date of 385 British plant species has advanced by 4.5 days over the past decade compared to the previous four decades (Fitter and Fitter 2002; Wolkovich et al. 2012). In Panama, flower and seed production increased during El Niño years (Wright and Calderón 2006). In Kibale, annual fruiting varied over 3.8-fold between 1998 and 2013 and fruiting was positively influenced by temperature, rainfall, and solar radiation. As we have documented such relationships among climate and phenology patterns in Kibale (Chapman et al. 2005; Chapman et al. 2018b; Chapman CA, Lawes MJ, Gogarten JF, Hou R, Omeja P, Sugiyama A, Kalbitzer U: A 50-year fruiting phenology record reveals different responses among rainforest tree species to changing climate, unpublished), we predict shifts in the composition of the tree community correspond to directional change in the climate at Kibale (Prediction 5). We develop scenarios of tree community response to climate change based on habitat preferences (e.g., trees that typically occur in wet valley bottoms will increase in abundance if the climate gets wetter).

\section{Methods}

\section{Study site and vegetation}

Kibale National Park, Uganda $\left(795 \mathrm{~km}^{2}\right)$ is in western Uganda $\left(0^{\circ} 13^{\prime}-0^{\circ} 41^{\prime} \mathrm{N}\right.$ and $\left.30^{\circ} 19^{\prime}-30^{\circ} 32^{\prime} \mathrm{E}\right)$ near the foothills of the Rwenzori Mountains (Struhsaker 1997; Chapman and Lambert 2000, Chapman et al. 2005). Kibale is dominated by mid-altitude (920-1,590 m), moist-evergreen forest that receives a mean annual rainfall of $1,655 \mathrm{~mm}$ (1970-2020). Our long-term study of vegetation was conducted in the compartment K30, which was first assessed for forest composition in December 1978 and the same plots resampled in May 2019-40 years and 5 months apart. K30 is a 282-ha area of old-growth forest that has been extensively studied since 1970. A description of the tree community and maps of the study plots can be found in Chapman et al. (Chapman and Chapman 1997; Chapman, et al. 2005; Chapman et al. 2010a) and Struhsaker $(1975,1997)$.

Rainfall data were collected immediately adjacent to the study area. The daily rainfall data were summarized per month. The collection of these meteorological data was maintained through rebel intrusions into the park and the COVID19 pandemic and data for only 8 of a total 612 months were incomplete and thus not included. For the missing 8 months, we fitted an ARIMA time series model with Fourier terms for seasonality to interpolate these values using all other values. Temperature data (daily minimum, $T_{\min }$, and maximum, $T_{\max }$ ) were collected over the same period. However, thermometers had to be replaced several times, and they were relocated twice (first by a distance of $\sim 1 \mathrm{~km}$, and then by only $30 \mathrm{~m}$ ). An analysis of the temperature data from 1970 to 2020 indicated that these changes in thermometer and location (hereafter sources) had impacts on measured temperature that were challenging to control for. For example, the magnitude of the difference between $T_{\min }$ and $T_{\max }$ appears to vary with the source (i.e., some thermometers show higher $T_{\max }$ and lower $\left.T_{\min }\right)$. Therefore, we used the CRU TS v.4.05 dataset (https://crudata.uea.ac.uk/cru/data/hrg/ (Harris et al. 2020). Temperature from this dataset was correlated with the different monthly temperature sources measured on the ground (Pearson's correlation coefficients for $T_{\max }: 0.50-0.79$; for $T_{\min }$ : $0.21-0.37$; see Table $\mathrm{S} 1$ ).

There has been a long history of human presence in the Kibale region. Pollen analyses and archeological studies indicate that there was widespread deforestation 
throughout much of Uganda between 2000 and 5000 years ago associated with the spread of Bantu-speaking agriculturalists (Langdale-Brown et al. 1964; Hamilton 1974, 1984; Hamilton et al. 1986; Taylor et al. 1999). Sediment cores near the study site indicate a second period of forest clearing at approximately 400 years ago (Taylor et al. 1999). Potsherds and grinding stones have been found in the forest (Struhsaker 1975; Mitani et al. 2000; Isabirye-Basuta and Lwanga 2008; Chesterman et al. 2019) and the decorations on the pottery are typical of the period between 200 and 400 years ago (Isabirye-Basuta and Lwanga 2008). In the $1950 \mathrm{~s}$, Osmaston (1959) described a small long-abandoned church in the center of the forest and soil analysis indicates that the grasslands enclosed within Kibale are of anthropogenic origin (Lang Brown and Harrop 1962). Kibale forest was established as a Crown Reserve between 1926 and 1932 for sustained hardwood timber production and became a National Park in 1993 (Struhsaker 1997; Naughton-Treves 1999; Chapman et al. 2005). The study area in Kibale (K-30, 282 ha) was not logged and there was no timber harvest before 1970 (Struhsaker 1975) and none has occurred since. Kibale is now well protected from poaching, timber harvesting, and agricultural encroachment. The Uganda Wildlife Authority (UWA) regularly (9.2 days a month; data from 2005 to 2017) sends out patrols to prevent encroachment (Hou et al. 2021) and poaching by snaring game is limited by find-and-remove programs (Hartell et al. 2020). The protection of the area by UWA, does not alter natural processes of forest disturbances, such as lightning strikes and the fires they cause in the forest, droughts, elephant damage, or landslides. The protection simply stops people harvesting large trees for timber, although some smaller trees are taken along the forest edge for fuelwood, but not in the K30 study area.

Nevertheless, natural disturbances in this area of Kibale are relatively rare. Given that the area receives two rainy seasons a year, fires in the grasslands do not penetrate the forest, lightening strikes have not been recorded in the forest in 50 years of continuous research presence, and because the hills are not very steep landslides are uncommon (in 50 years one is known in a $15-\mathrm{km}^{2}$ area - and covers an area of $482 \mathrm{~m}^{2}$ ) (Chapman et al. 1999). Natural tree falls do occur but they are typically not large (mean size $256 \mathrm{~m}^{2}$, range 100-663 $\mathrm{m}^{2}$ ) (Kasenene 1987), and the mean annual rate of natural tree falls expressed as a percentage of all large stems is approximately $1.4 \%$, which is similar to the rates reported for other old-growth forests (Skorupa and Kasenene 1984).

The seed disperser and seed predator populations in Kibale have been partially released from predator pressure by the hunting out of large carnivores prior to the 1970 s. While lions occasionally pass through the park, leopards are very rare (sighted by the CAC 6 times in 32 years), which likely leaves smaller carnivores, like the golden cat (Caracal aurata), as the apex predators in the system (Mills et al. 2019).

\section{Botanical sampling and species categorization}

In August 1971, transects were established along compass bearings and all woody plants greater than $10 \mathrm{~m}$ in height within $2.5 \mathrm{~m}$ of the center of the transect were identified. The set of transects were $2,833 \mathrm{~m}$ in length in an area of approximately $2 \mathrm{~km}^{2}$. The transects were resampled in December 1978, at which time the Diameter at Breast Height (DBH) of the trees was measured. We used these 1978 data (436 trees) to ensure that the same trees were sampled at different times. These transects have been maintained over the decades. The transects were resampled in May and June 2018 and 2019 and differences in the presence or absence of trees were investigated and clarified and 2019 measurements were used in analyses.

We categorized species as light-demanding or shadetolerant from a statistical assessment of stem distribution among habitats described in Zanne and Chapman (2005) (see also Zanne et al. 2005). Briefly, over two years, Zanne and Chapman (2005) quantified tree density (newly germinated seedlings to adults) in each of four canopy types (closed canopy forest, treefall gaps, forest/ grassland edge, and grassland) for 63 species. For rare species not found in these habitat plots, categorization is based on descriptions in Eggling and Dale (1952), Polhill (1952-), Hamilton (1991), Katende et al. (1995), Lwanga (1996), and an independent assessment made by Peter Grubb, based on his observations of seedlings and saplings in Kibale and elsewhere (Grubb, P. pers. comm.). Since the disturbance that occurred in Kibale happened a few hundred years ago, we are not considering pioneer species that rapidly colonize after disturbance and die out 20-40 years later (e.g., Cecropia, Muntingia, Trema), as such light demanding species do not occur in significant numbers in our sample (i.e., there were only one Trema stem found in each sampling period).

Large canopy-level trees were assigned as large-gap specialists if they preferentially recruited into gaps that were larger than those created by tree falls (LangdaleBrown et al. 1964; Chapman et al. 1999; Chapman et al. 2008; Isabirye-Basuta and Lwanga 2008). Building on habitat associations of trees in Kibale (Zanne and Chapman 2005), Chapman et al. (2010a) identified four largegap species that were not early successional (pioneer) species (i.e., species that die within 20-40 years after they colonize a disturbance). These four species often persist to be canopy level trees in old-growth forest: $\mathrm{Cel}$ tis africana, Celtis gomphophylla, Diospyros abyssinica, and Funtumia latifolia. The lifespan of these trees is 
unknown, but it is likely that they live at least a few hundred years. To further verify if these species typically recruit after large anthropogenic disturbances, we established seven 200 by $10 \mathrm{~m}$ plots in the study area and seven similar plots in a large disturbed area immediately adjacent to the study area (Nyakatojo 86.2 ha). This disturbed area was an anthropogenically derived grassland, dominated by elephant grass (Pennisetum purpurem), but between 1967 and 1968 the area was converted to a pine plantation (Kingston 1967; Struhsaker 1975). The pines were harvested in 1998 and the natural forest was left to regenerate (Zanne et al. 2001; Duncan and Chapman 2003; Omeja et al. 2016). We expected that the four species that usually recruit into large disturbed areas would dominate this recently disturbed area. This proved to be true and thus these four species were used to test Prediction 4; that they would decline in abundance over the 40 years as they were expected to recruit fewer trees than other species.

\section{Changes in seed disperser and herbivore populations}

To evaluate if changes in the abundance of the seed dispersing frugivores $(F)$ or herbivores $(H)$ have driven species shifts in the tree community (Predictions 1 and 2), we monitored changes in the relative abundance of the following mammal species; primates - redtail monkeys (Cercopithecus ascanius - F), blue monkeys (C. mitis $F$ ), and mangabeys (Lophocebus albigena - F), red colobus (Piliocolobus tephrosceles - $H$ ) and black-and-white colobus (Colobus guereza - H); ungulates - red duiker (Cephalophus harveyi - H), blue duiker (Cephalophus moniticola - H), bushbuck (Tragelaphus scriptus - H); and bushpig (Potamochoerus larvatus - $H$ ); and elephants - forest elephants (Loxodonta cyclotis - H), savanna elephants (Loxodonta africana - $H$ ), and their hybrids.

A single species may have multiple ecological roles, such as sometimes being a folivore, but also eating fruits and dispersing seeds. The classification of predominantly $F$ or $H$ was based on published descriptions of animal species' diets (Oates 1977; Rudran 1978; Olupot 1998; Chapman et al. 2002; Stickler 2004; Rode et al. 2006; Struhsaker 2017) and extensive observation and sampling of dung (CAC unpublished data). The potential effects of elephants and the primates on forest dynamics are clearly documented (Wing and Buss 1970; Oates 1977; Rudran 1978; Olupot 1998; Chapman et al. 2002; Stickler 2004; Rode et al. 2006; Omeja et al. 2014). However, these effects are not so clear for less well-known duikers, bushbuck, and bushpigs. While, duikers are largely frugivorous, acting as seed dispersers (Gautier-Hion et al. 1980; McCoy 1995; Brugiere et al. 2002; Molloy and Hart 2002), their effect on seedling dynamics is only partially understood (Lwanga 1994). Bushbuck are browsers (Gautier-Hion et al. 1980) but their influence on forest dynamics is not known. Bushpigs forage on the forest floor often eating tubers and are known to prey on seeds of several prominent canopy tree species, including: Balanites wilsoniana, Chrysophyllum albidum, Cordia millenii, Mimusops bagshawei, and Parinari excelsa. While some seeds pass through their gut intact, this is uncommon (Rafael Reyna-Hurtado unpublished data, Ghiglieri et al. 1982). Their role in forest dynamics is poorly understood.

We assessed primate abundance (groups/km walked) in six censuses, each of a year's duration, between 1970 and 2019 (1970 (Struhsaker 1975), 1980 (Skorupa 1988), 1996, 2005, 2014, 2019 (Chapman et al. 2010b; Chapman et al. 2018a, Chapman 2019 unpublished data)). We conducted 165 transect walks and covered $660 \mathrm{~km}$. To minimize sources of error, we used the same methods each year and walked the same $4 \mathrm{~km}$ transect once per month for 12 months. Censuses were conducted between 0700 and $1400 \mathrm{~h}$ at a speed of approximately $1 \mathrm{~km}$ per hour. The census team comprised experienced observers. With these methods, we estimated the number of groups per $\mathrm{km}$ walked. It is impossible to obtain accurate group counts during these censuses because some species occurred in groups of over 150 animals, while the cryptic behaviour of others make it difficult to detect all individuals. Thus, we separately evaluated group size in three periods (July 1996 - May 1998, July 2010 - May 2011; May 2017 - May 2018, $N=220$ group counts) (see Gogarten et al. 2015 for an analysis of the first two periods). Three observers spent approximately eight days each month with the sole aim of accurately estimating group sizes.

For duikers, bushbuck, bushpigs and elephants, we evaluated changes in abundance through track and dung counts made in 1996, 2005, 2014, and 2019 along the same $4 \mathrm{~km}$ transect used to determine the abundance of the primates. A single set of tracks in a line was counted as one sighting. Both dung and tracks were removed after they were counted to ensure that they were not repeatedly counted. The tracks and dung of the two duiker species can be distinguished when the sign is of good quality, but quality declines over time and depends on the season and environment. Thus, it was not always possible to distinguish the species, so we report a combined duiker value. Censuses of duikers, bushbuck, and bushpigs in Kibale are available from prior to 1996 (Nummelin 1990; McCoy 1995; Struhsaker 1997; Lwanga 2006); however, there are methodological differences among studies (Struhsaker 1997) that make comparisons problematic.

\section{Feeding preferences of seed disperser and herbivore populations}

To examine Prediction 1 that changes in the abundance of seed dispersing frugivores in relation to all seed 
dispersal agents, results in a corresponding change in the abundance of fruit-bearing tree species, we determined the 10 most frequently used fruiting tree species for blue monkeys (Rudran 1978), redtail monkeys (Stickler 2004 only in the K30 area), and mangabeys (Olupot 1998 data from 1992 to 1993). These species often eat fruits from the same species and this comparison produced 17 tree species that were examined for changes in their abundance. Prediction 2 was evaluated for folivorous primates and the tree species most likely to be killed by colobine foraging (Chapman et al. 2013a) were monitored for their change in abundance from 1978 to 2019. In addition, we expected that tree species preferred by elephants would change in abundance with changes in elephant numbers as elephants would be killed them either because by pushing them over or debarking them. The species preferred by elephants were determined from several studies (Kasenene 1980; Kasenene 1984; Kasenene 1987; Lwanga 1994; Struhsaker et al. 1996; Omeja et al. 2014). To quantify elephant feeding preferences their tree species selection ratio was calculated (for details of the calculation see Omeja et al. 2014). A ratio greater than one indicates the species was selectively browsed. The foraging preferences of bushpigs, duikers, or bushbuck are insufficiently known to permit predictions of how they may affect forest composition change. However, we report on changes in the abundance of these species so that evaluations may be made in the future. To evaluate Prediction 3 that lightdemanding species should decrease in abundance between 1978 and 2019, while shade tolerant species increase, we not only looked at overall abundance, but examined changes in abundance of different size classes of trees and rank abundance curves. Such analyses would reveal any pulses of recruitment.

\section{Analysis}

We estimated sampling saturation or completeness and species richness of the tree community using the estimator of sample coverage in the R package 'iNEXT' (Hsieh et al. 2013). Because species richness is not sensitive to species abundances and gives disproportionate weight to rare species, we measured tree species diversity with Hill's numbers (Jost 2006), using the 'entropart' package (Marcon and Hérault 2013) for R version 4.0.2 (R-CoreTeam 2020). We used the following Hill's numbers (Gotelli and Chao 2013): species richness (0D); the number of 'common' species in the community (1D) measured as the exponential of Shannon's entropy; and the number of 'very abundant' or 'dominant' species in the community (2D), measured as the inverse of the Simpson index (Chao et al. 2012). We also calculated Shannon's diversity index $\left(H^{\prime}\right)$.
Climate change influences forest plant community composition and structure, either directly (e.g., causing tree or seedling mortality) or indirectly (e.g., causing the disruption of processes such as pollination). We investigated changes in several descriptors of climate over the period 1970-2020. For rainfall, we examined annual totals and monthly averages calculated over the entire period. For both maximum and minimum temperature $\left(T_{\max }\right.$ and $\left.T_{\min }\right)$, we examined mean annual monthly temperatures, and monthly means over the period 19702020. In addition to general summaries, including mean values, and the range of values, we examined the variation (Coefficient of Variation; CV) in annual trends from 1970 to 2020 using a time series decomposition. For rainfall, $T_{\min }$, and $T_{\max }$, we applied a "Seasonal and Trend decomposition using Loess" (STL) in the "fabletools' package for R. To investigate long-term changes in rainfall and temperature, we applied linear models to the trend component from these decompositions as the outcome variable and date as the predictor variable.

\section{Results}

The forest in 1978 and 2019

More trees were present on the sampled transects in 2019 (508) than in 1978 (436), but species richness remained similar, decreasing by only two species (Tables 1 and 2). Diversity $\left(H^{\prime}\right)$ declined as the number of dominant species (2D) increased, suggesting the community assemblage became more even over the 40 years, particularly with respect to the common species.

\section{Change in Kibale's climate}

The average annual rainfall from 1970 to 2020 was 1,646 $\mathrm{mm}$ and ranged from 1,197 $\mathrm{mm}$ in 1993 to 2,214 $\mathrm{mm}$ in 1996 (Fig. 1; all summary statistics are also shown in Table S21); however, time series analysis showed no significant variation or change in rainfall over the long-term (Table S3). According the linear model using the trend component of the time series analysis, rainfall increased by 0.06 $\mathrm{mm}$ per year and by $3 \mathrm{~mm}$ over the 50 years but this effect was not significant $(P=0.18$; see Table $\mathrm{S} 3)$.

There are two distinct rain seasons in Kibale, with a first peak in April and a second peak in October. On average, the wettest month of the year (October) received $253 \mathrm{~mm}$ rainfall, whereas the driest month (January) received $59.6 \mathrm{~mm}$. According to the CRU TS v4.05 dataset, the annual average monthly $T_{\max }$ at the location of the field site from 1970 to 2020 was $27.89{ }^{\circ} \mathrm{C}$ and ranged from $27.07{ }^{\circ} \mathrm{C}$ to 1975 to $28.9{ }^{\circ} \mathrm{C}$ in 2009 . The annual average $T_{\min }$ was $15.98{ }^{\circ} \mathrm{C}$, ranging from $15.06{ }^{\circ} \mathrm{C}$ to 1971 to $17.18{ }^{\circ} \mathrm{C}$ in 2009 . According to the linear model with the trend component, both the annual average monthly $T_{\max }$ and $T_{\min }$ increased over time (Table S3). $T_{\max }$ increased by $0.021{ }^{\circ} \mathrm{C}$ per year and by $1.05{ }^{\circ} \mathrm{C}$ 
Table 1 The density (trees per ha) of the twenty five most common tree species $>10 \mathrm{~cm} \mathrm{DBH}$ in an old-growth section of forest in Kibale National Park, Uganda that was enumerated in 1978 and 2019

\begin{tabular}{|c|c|c|c|c|c|}
\hline \multicolumn{3}{|l|}{1978} & \multicolumn{3}{|l|}{2019} \\
\hline Family & Species & Density (ha) & Family & Species & Density (ha) \\
\hline Ebenaeae & Diospyros abyssinica & 78.36 & Ebenaeae & Diospyros abyssinica & 63.54 \\
\hline Ulmaceae & Celtis gomphophylla & 40.95 & Annonaceae & Uvariopsis congensis & 40.24 \\
\hline Annonaceae & Uvariopsis congensis & 33.18 & Ulmaceae & Celtis gomphophylla & 34.59 \\
\hline Bignoniaceae & Markhamia lutea & 29.65 & Apocynceae & Funtumia africana & 33.89 \\
\hline Apocynceae & Funtumia africana & 26.12 & Moraceae & Trilepisium madagascariense & 29.65 \\
\hline Olacaceae & Strombosia scheffleri & 8.47 & Bignoniaceae & Markhamia lutea & 19.77 \\
\hline Rutaceae & Vepris nobilis & 8.47 & Olacaceae & Strombosia scheffleri & 17.65 \\
\hline Malvaceae & Dombeya kirkii & 7.06 & Rutaceae & Vepris nobilis & 16.24 \\
\hline Leguminosae & Millettia dura & 6.35 & Ulmaceae & Celtis africana & 12.00 \\
\hline Ulmaceae & Chaetachme aristata & 5.65 & Ulmaceae & Chaetachme aristata & 10.59 \\
\hline Ulmaceae & Celtis africana & 4.94 & Sapindaceae & Lepisanthes senegalensis & 8.47 \\
\hline Sapindaceae & Lepisanthes senegalensis & 4.24 & Sapotaceae & Mimusops bagshawei & 7.06 \\
\hline Sapotaceae & Chrysophyllum gorungosanum & 3.53 & Sterculiaceae & Leptonychia mildbraedii & 5.65 \\
\hline Euphorbiaceae & Neoboutonia macrocalyx & 3.53 & Sapindaceae & Pancovia turbinata & 5.65 \\
\hline Oleaceae & Olea capensis & 3.53 & Guttiferae & Symphonia globulifera & 4.94 \\
\hline Rhizophoraceae & Cassipourea abyssinica & 2.82 & Leguminosae & Albizia grandibracteata & 4.24 \\
\hline Chrysobalanaceae & Parinari excelsa & 2.82 & Boraginaceae & Ehretia cymosa & 3.53 \\
\hline Rubiaceae & Vangueria apiculata & 2.82 & Rutaceae & Fagaropsis angolensis & 3.53 \\
\hline Olacaceae & Chionanthus africanus & 2.12 & Oleaceae & Olea capensis & 3.53 \\
\hline Meliaceae & Lovoa swynnertonii & 2.12 & Chrysobalanaceae & Parinari & 2.82 \\
\hline \multirow[t]{2}{*}{ Annonaceae } & Monodora myristica & 2.12 & Sapotaceae & Pouteria altissima & 2.82 \\
\hline & Unknown 1 & 2.12 & Rhizophoraceae & Cassipourea abyssinica & 2.12 \\
\hline Moraceae & Ficus sansibarica & 1.41 & Rubiaceae & Dictyandra arborescens & 2.12 \\
\hline Moraceae & Ficus exasperata & 1.41 & Leguminosae & Millettia dura & 2.12 \\
\hline Apocynceae & Tabernaemontana odoratissima & 1.41 & Euphorbiaceae & Shirakiopsis elliptica & 2.12 \\
\hline
\end{tabular}

Table 2 Descriptions of the tree community in 1978 and 2019 in an old-growth section of forest in Kibale National Park, Uganda. 1D is the exponential of Shannon's entropy and is interpreted as the number of 'common' species in the community, which weights each species according to its frequency in the community, and 2D is the inverse Simpson concentration, which favors abundant species and is therefore interpreted as the number of 'very abundant' or 'dominant' species in the community

\begin{tabular}{|c|c|c|c|c|}
\hline & \multicolumn{2}{|l|}{ All Species } & \multicolumn{2}{|c|}{ Top Ten Species } \\
\hline & 1978 & 2019 & 1978 & 2019 \\
\hline Abundance & 436 & 508 & 345 & 391 \\
\hline Completeness & 0.97 & 0.98 & & \\
\hline Richness (OD) & 45 & 43 & & \\
\hline Number of common species (1D) & 15.5 & 18.8 & & \\
\hline Number of dominant species (2D) & 8.7 & 12.4 & & \\
\hline Shannon Diversity $\left(H^{\prime}\right)$ & 71.8 & 78.1 & 84.6 & 93.5 \\
\hline Mean DBH & 23.7 & 28.0 & 21.3 & 26.4 \\
\hline Percentage of Light demanding Species ( $n$ ) & $65.4 \%(279)$ & $50.8 \%(253)$ & $68.7 \%(237)$ & $50.1 \%(196)$ \\
\hline Percentage of Shade-tolerant species $(n)$ & $34.5 \%(147)$ & $49.2 \%(245)$ & $31.3 \%(108)$ & $49.9 \%(195)$ \\
\hline
\end{tabular}




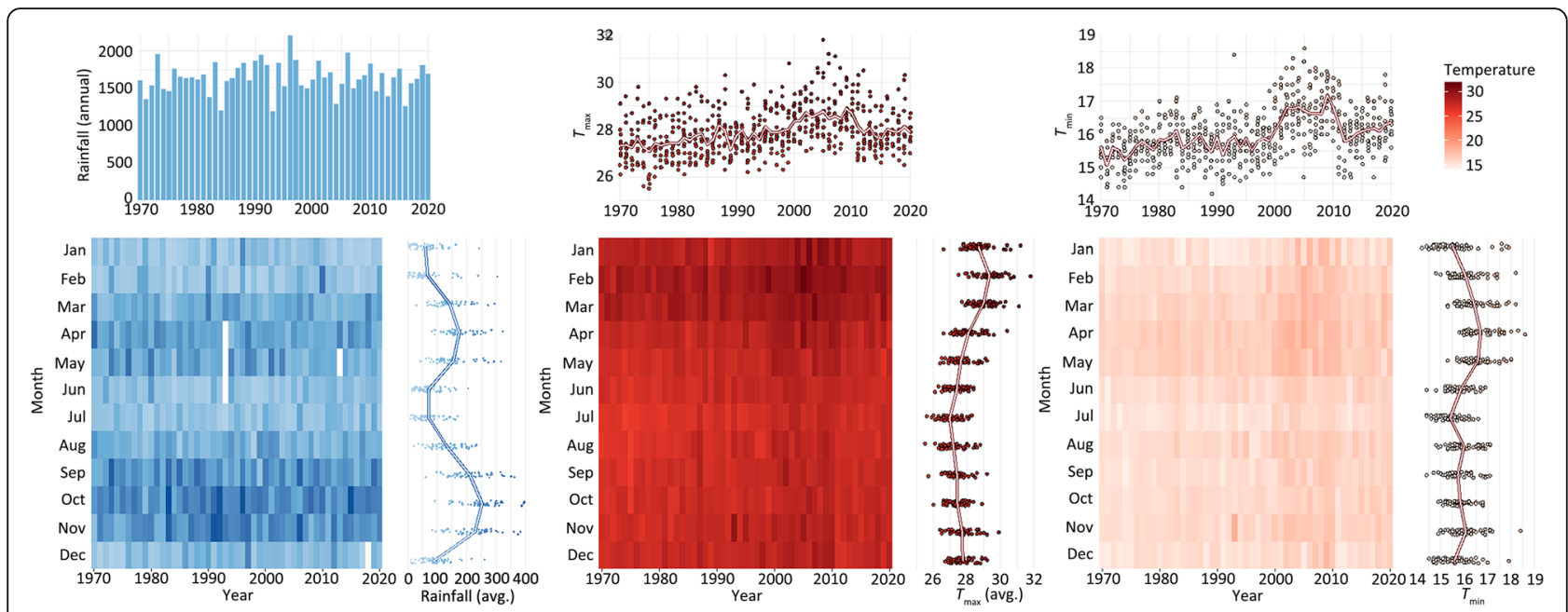

Fig. 1 Patterns of rainfall, maximum temperature $\left({ }^{\circ} \mathrm{C}, T_{\text {max }}\right)$ and minimum temperature $\left({ }^{\circ} \mathrm{C}, T_{\min }\right)$ between 1970 and 2020 for the area near Makerere University Biological Field Station in Kibale National Park, Uganda. For details, see text

over 50 years, while $T_{\text {min }}$ increased by $0.021{ }^{\circ} \mathrm{C}$ per year and by $1.06{ }^{\circ} \mathrm{C}$ over 50 years. In contrast to rainfall, there are only single annual peaks for $T_{\max }$ and $T_{\min }$. Maximum monthly temperatures are usually recorded in February with an average of $29.35{ }^{\circ} \mathrm{C}$, and the lowest $T_{\min }$ in July with an average of $15.41{ }^{\circ} \mathrm{C}$.

\section{Changes in animal abundance}

While the number of groups of frugivorous seeddispersing primates detected per $\mathrm{km}$ walked fluctuated slightly over time, there was no significant change in the relative abundance of groups over the last 50 years (Table 3). The only exception to this trend was a decrease in abundance of blue monkeys. This decrease has been monitored and is occurring park-wide (Butynski 1990; Chapman et al. 2000; Chapman et al. 2010b). However, mean group size increased for all frugivorous primate species between 1996 and 2018 (Table 3) and thus primate density in the area increased.

Table 3 The relative abundance of herbivorous/folivorous mammals that can often suppress regeneration and the abundance of seed-dispersing frugivorous primates that promote regeneration in an old-growth forest in Kibale National Park, Uganda. For the primate species we also include data on group sizes estimates from which we calculated individuals / km walked in the final survey

\begin{tabular}{|c|c|c|c|c|c|c|c|c|c|}
\hline Year & Elephant & Duiker & Bushbuck & Pig & Red colobus & B\&W colobus & Redtail monkey & Blue monkey & Mangabey \\
\hline \multicolumn{10}{|c|}{ Tracks or Groups per km walked } \\
\hline 1970 & & & & & 0.97 & 0.22 & 0.70 & 0.45 & 0.09 \\
\hline 1980 & & & & & 1.14 & 0.12 & 0.64 & 0.39 & 0.16 \\
\hline 1996 & 0.05 & 1.11 & 0.09 & 0.13 & 0.64 & 0.17 & 0.35 & 0.09 & 0.40 \\
\hline 2005 & 7.00 & 8.71 & 1.25 & 1.75 & 0.47 & 0.21 & 0.41 & 0.17 & 0.19 \\
\hline 2008 & 3.19 & 6.87 & 1.62 & 4.63 & 0.67 & 0.33 & 0.73 & 0.14 & 0.32 \\
\hline 2014 & 6.66 & 10.16 & 1.23 & 2.14 & 0.56 & 0.27 & 0.56 & 0.15 & 0.27 \\
\hline 2019 & 6.68 & 8.12 & 1.68 & 0.91 & 0.62 & 0.29 & 0.42 & 0.10 & 0.23 \\
\hline \multicolumn{10}{|c|}{ Group Sizes } \\
\hline 1996 & & & & & 35.26 & 8.89 & 20.50 & 9.74 & 12.05 \\
\hline 2010 & & & & & 47.47 & 7.89 & 13.99 & 10.60 & 17.31 \\
\hline 2018 & & & & & 71.90 & 15.14 & 23.30 & 15.10 & 25.60 \\
\hline \multicolumn{10}{|c|}{ \# of Individuals per km walked } \\
\hline 1996 & & & & & 22.57 & 1.51 & 7.18 & 0.88 & 4.82 \\
\hline 2010 & & & & & 31.80 & 2.60 & 10.21 & 1.48 & 5.54 \\
\hline 2019 & & & & & 44.58 & 4.39 & 9.79 & 1.51 & 5.89 \\
\hline
\end{tabular}


Similarly, the abundance of folivorous primates - red colobus and black-and-white colobus - groups in the area varied slightly between 1970 and 2019, but with no overall change in group density. However, again group sizes increased and thus population density (number of individuals per $\mathrm{km}$ walked) increased (Table 3).

In general, the abundance of elephants, duikers, and bushbuck increased between 1996 and 2005 and has remained relatively stable since. In contrast, bushpig abundance increased from 1996 to 2008 and declined thereafter (Table 3).

\section{Evaluation of the predictions}

Prediction 1: an increase in the abundance of seed dispersing frugivores, in relation to all seed dispersal agents, is expected to correspond to an increase in the abundance of fruit bearing trees prominent in their diet and vice versa

Of the 17 preferred species in the diet of the frugivorous primates, seven increased in abundance as predicted, three declined, and for seven there was no change in abundance (Table 4). Given that greater rates of seed dispersal with increasing frugivore numbers would take time to be represented as fruit-bearing trees, we examined if there was an increase in the abundance only in the smallest size classes. Considering only those stems between 10 and $15 \mathrm{~cm}$ $\mathrm{DBH}$, four species increased as predicted, five decreased, and for the remainder there was no change in abundance. Thus, Prediction 1 was not supported.
Prediction 2: as the abundance of folivorous primates increases, the abundance of heavily defoliated tree species declines

Of the 13 tree species frequently used by colobus, seven occurred in the sample area. Of these (90 trees across both sampling years, 6.9 individuals per species, range 1-40), four species support the prediction, two species increased contrary to the prediction, and for one species there was no change (Table 5). Considering only the two species with $\geq 10$ individuals (Dombeya mukole, Markhamia lutea), both species declined in abundance in accordance with the prediction.

Also, with respect to Prediction 2, we expected that as elephants increased in abundance, the tree species that elephants preferentially fed on would decline. There were twelve highly preferred elephant food species (Table 6). Of those in the area, $56 \%$ increased in abundance, the opposite to what was expected, $33 \%$ decreased as expected, $11 \%$ remained the same (Table 6). Considering only those species with $\geq 10$ individuals, all three increased in abundance. Thus, Prediction 2 as it applies to elephants was not supported.

\section{Prediction 3: as the forest was disturbed by humans prior to written history, we predicted that light-demanding species would decrease in abundance between 1978 and 2019, while shade-tolerant species would increase}

As predicted, light-demanding species decreased in abundance $(1978-65.4 \%, 2019-50.8 \%)$, while the abundance of shade-tolerant species increased $(1978-34.5 \%, 2019-$

Table 4 The density (trees per ha) of fruiting tree species in an old-growth section of forest in Kibale National Park, Uganda that was enumerated in 1978 and 2019 and the percentage of time three common frugivorous primates spent feeding on their fruit. The species listed are those that were the ten most eaten trees for any of these primates

\begin{tabular}{|c|c|c|c|c|c|c|}
\hline Family & Species & Density 1978 & Density 2019 & Redtail diet (\%) & Blue diet (\%) & Mangabey diet (\%) \\
\hline Sapotaceae & Blighia unijugata & 0 & 1.41 & & & 3.93 \\
\hline Ulmacaea & Celtis africana & 4.94 & 12.00 & & 8.2 & 2.37 \\
\hline Ulmacaea & Celtis gomphophylla & 40.95 & 34.59 & 20.5 & 5.07 & 16.98 \\
\hline Ulmacaea & Chaetchme aristata & 5.65 & 10.59 & & 1.4 & \\
\hline Euphorbiaceae & Croton macrostachys & 0 & 0 & & & 5.84 \\
\hline Ebenaeae & Diospyros abyssinica & 78.36 & 63.54 & 5.4 & 3.29 & 8.5 \\
\hline Moraceae & Ficus samsobaroca & 1.41 & 0 & & & 5.79 \\
\hline Moraceae & Ficus sur & 0 & 0 & & & 0.16 \\
\hline Moraceae & Ficus congensis & 0 & 0 & & & 0.61 \\
\hline Moraceae & Ficus exasperata & 1.41 & 0.71 & 1.7 & 4.49 & 6.29 \\
\hline Oleaceae & Linociera johnsonii & 0 & 0 & & & \\
\hline Euphorbiaceae & Macaranga schweinfurthii & 0 & 0 & 3.4 & & \\
\hline Sapotaceae & Mimusops bagshawei & 0 & 7.06 & 3.8 & 3.05 & \\
\hline Sapotaceae & Pancovia turbinata & 0.71 & 5.65 & & 8.17 & \\
\hline Rosaceae & Parinari excelsa & 0 & 2.82 & & 2.13 & \\
\hline Rutaceae & Vepris nobilis & 8.47 & 14.83 & & 6.53 & \\
\hline Annonaceae & Uvariopsis congensis & 33.18 & 40.24 & & 6.53 & 5.11 \\
\hline
\end{tabular}


Table 5 The species documented to have been killed by extensive red colobus foraging based on long-term observation in Kibale National Park, Uganda (Chapman et al. 2013a) and their density (per ha) in 1978 and 2019 in the surveyed forest. Rare and edge species known to be killed by the red colobus were not found along the surveyed areas

\begin{tabular}{|c|c|c|c|c|c|}
\hline Family & Tree species & Descriptor & Density 1978 & Density 2019 & Trend \\
\hline Fabaceae & Albizia grandibracteata & Forest & 0 & 4.24 & Up \\
\hline Sterculiaceae & Dombeya mukole & Forest & 7.06 & 0 & Down \\
\hline Moraceae & Ficus exasperata & Forest & 1.41 & 0.71 & Down \\
\hline Bignoniaceae & Markhamia lutea & Forest & 28.24 & 19.77 & Down \\
\hline Euphorbiaceae & Neoboutonia macrocalyx & Forest & 3.53 & 0 & Down \\
\hline Rosaceae & Prunus africana & Forest & 0.71 & 0.71 & Same \\
\hline Euphorbiaceae & Sapium ellipticum & Forest & 0 & 2.12 & Up \\
\hline Rutaceae & Fagara angolensis & Rare & 0 & 0 & \\
\hline Fabaceae & Newtonia buchananii & Rare & 0 & 0 & \\
\hline Guttiferae & Harungana madagascarensis & Edge & 0 & 0 & \\
\hline Myrtaceae & Eucalyptus grandis & Edge & 0 & 0 & \\
\hline Lauraceae & Persea americana & Edge & 0 & 0 & \\
\hline Fabaceae & Sesbania sp. & Edge & 0 & 0 & \\
\hline
\end{tabular}

$49.2 \%$ ) (Table 2). Consistent trends were observed for all species and the ten most abundant species (Table 2). Comparing rank abundance curves there was a decrease in the dominance of light-demanding species and an increase for shade-tolerant species (Fig. 2). Comparing the sizefrequency distributions of light-demanding and shadetolerant species, they follow the expected J-shaped curve (Fig. 3). The increase in shade-tolerant species was particularly marked in the smaller DBH size classes $(<40 \mathrm{~cm} \mathrm{DBH})$ and shade-tolerant species dominated the $10-19.9 \mathrm{~cm} \mathrm{DBH}$ size class (Fig. 3). Thus, Prediction 3 was supported.
Prediction 4: large-gap tree species were predicted to generally decline in abundance as they represent senescing individuals that recruited into disturbed areas $200 \quad 400$ years ago

Four tree species are known to recruit into large disturbed areas (Chapman et al. 2010a). The density of these four species was greater in the recently disturbed area (Nyakatojo) adjacent to our study site (Celtis africana - Nyakatojo proportion 5.4 individuals per ha, oldgrowth 4.4; Celtis gomphophylla - 19.8, 12.8; Diospyros abyssinica - 15.6, 10.0; Funtumia latifolia 11.7, 2.5), thus

Table 6 Elephant selection ratios reported from four different studies in Kibale National Park, Uganda between 1962 and 2013 and the density (per ha) of stems of these species found during our sampling in 1978 and 2019

\begin{tabular}{|c|c|c|c|c|c|c|c|c|c|c|}
\hline Family & Tree species & 1962 & $1964^{a}$ & 1978 & $1979^{b}$ & $1993^{c}$ & $20122013^{d}$ & Average & 1978 & 2019 \\
\hline Moraceae & Antiaris toxicaria & 2.85 & & 2.08 & & 3.47 & 6.61 & 3.75 & 0 & 0 \\
\hline Fabaceae & Newtonia buchananii & 2.12 & & 1.6 & & 4.66 & 5.22 & 3.40 & 0 & 0 \\
\hline Sapotaceae & Mimusops bagshawei & 3.21 & & 0.63 & & 4.32 & 2.33 & 2.62 & 1.41 & 7.06 \\
\hline Moraceae & Ficus exasperata & 0.96 & & $\mathrm{n} / \mathrm{a}$ & & 3.94 & 2.5 & 2.47 & 1.41 & 0.71 \\
\hline Sapindaceae & Blighia unijugata & 2.8 & & $\mathrm{n} / \mathrm{a}$ & & 3 & 1.06 & 2.29 & 0 & 1.41 \\
\hline Ulmacaea & Celtis africana & 3.42 & & 3.27 & & 1.22 & 0.68 & 2.15 & 4.94 & 9.88 \\
\hline Annonaceae & Monodora myristica & 1.69 & & 1.75 & & 0 & 5.06 & 2.13 & 2.12 & 1.41 \\
\hline Moraceae & Trilepsium madagascariense & 2.95 & & 2.29 & & 2.72 & 0.38 & 2.09 & 4.94 & 29.65 \\
\hline Meliaceae & Lovoa swynnertonii & 2.85 & & 0.82 & & 3.56 & 1 & 2.06 & 2.12 & 1.41 \\
\hline Rosaceae & Parinari excelsa & 1.17 & & 0.19 & & 5.75 & 0.61 & 1.93 & 2.82 & 2.82 \\
\hline Olacaceae & Strombosia scheffleri & 2.66 & & 0.66 & & 4.06 & 0.28 & 1.92 & 8.47 & 17.65 \\
\hline Meliaceae & Trichilia splendida & 2.2 & & 1.9 & & 0.71 & 2.02 & 1.71 & 0 & 0 \\
\hline Average & & 2.35 & & 1.46 & & 2.9 & 2.14 & 2.38 & & \\
\hline
\end{tabular}

${ }^{a}$ Data from Wing and Buss 1970, sampling done between 1962 and 1964 and included the whole park

b Data from Kasenene (1980; 1984; 1987) sampling done in 1978 and 1979 and included forestry compartments K30 and K14 (average of compartments presented)

' Data from Lwanga (1994), sampling done in 1993, and includes forestry compartments K30 and K15 (average of compartments presented)

d Data from Omeja et al. (2014) done in 2012 and 2013, and includes forestry compartments K30, K14, and K15 (average of compartments presented) 


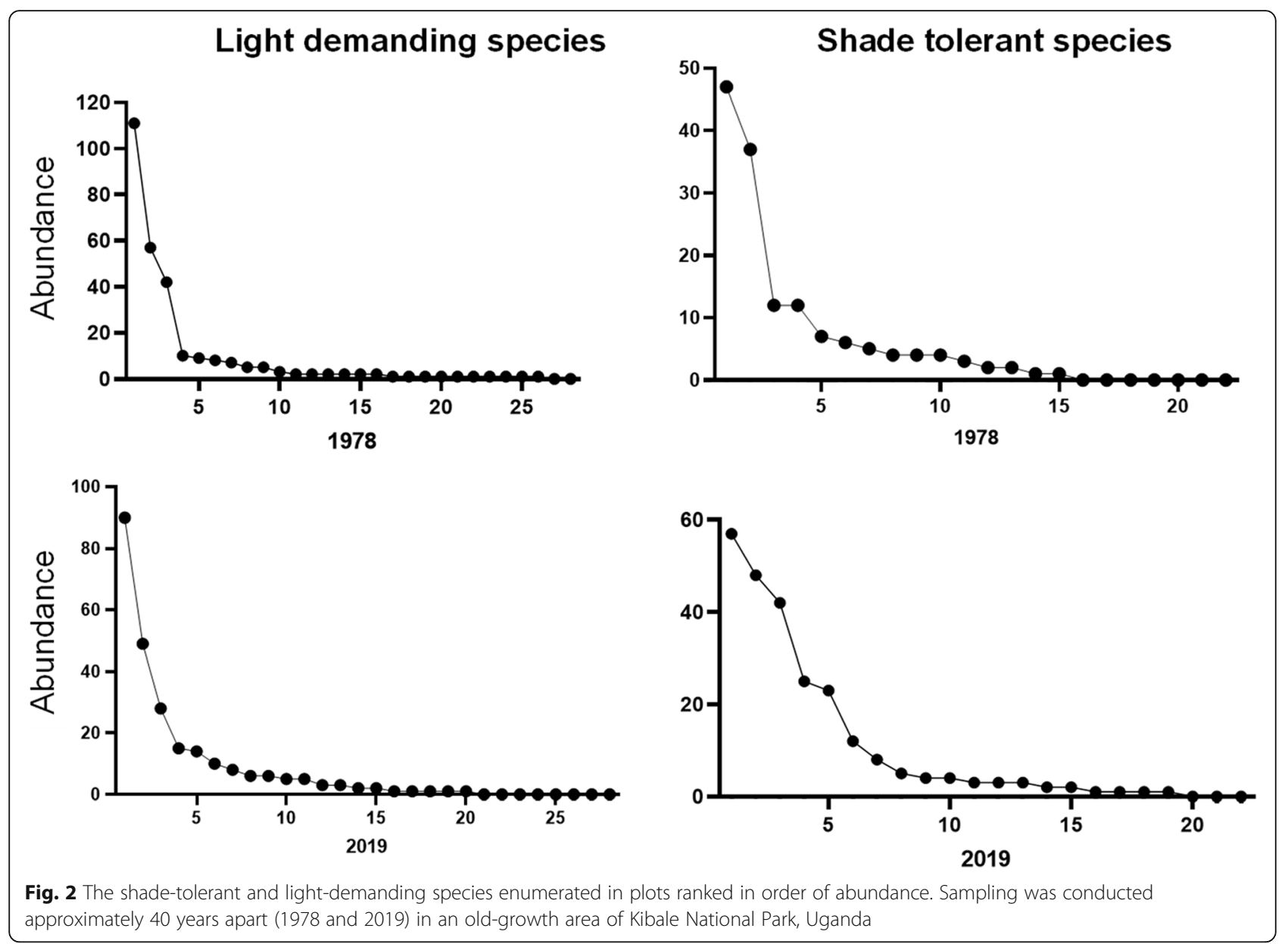

these species are undoubtedly large-gap specialists. $C$. gomphophylla and $D$. abyssinica declined in abundance in the old-growth forest between 1978 and 2019; however, C. africana and F. latifolia did not. Thus, Prediction 4 was not upheld.

Finally, in Prediction 5: we argued that a directional change in the climate in Kibale should be associated with a species shift in the composition of the tree community

If rainfall had changed and temperature remained constant, we expected species common in valley bottoms to increase over time. If temperature and rainfall had changed, we could have used the elevational gradient in Kibale with its cooler wetter conditions in the north and hotter and drier conditions in the south to test predictions on how the abundance of specific tree species would change. However, these patterns were not found. Thus, while $T_{\max }$ and $T_{\min }$ have both increased significantly over the 50 years, we have no means to predict a priori how individual species would respond.

\section{Discussion}

There were no major disturbances in the study forest in recorded history and correspondingly the changes in the forest structure that we documented between 1978 and 2019 were subtle. We recorded slightly more trees in the second enumeration, but species richness was similar and the tree community assemblage became more evenly distributed towards shade-tolerant species typical of old growth forest. To gain further insights to what might be driving changes in tree community composition, we examined potential effects of changes in the populations of seed dispersing and herbivorous mammals, human induced disturbance, and climate on putative changes to the tree community over the last 40 years.

Animal populations increased in density, which we predicted would affect the tree community. Folivorous and frugivorous primates have steadily increased in abundance. The reasons for this increase or the general increase in group size is not yet known (Gogarten et al. 2015; Chapman et al. 2018a). Similarly, the elephant population in Kibale increased substantially between our two sampling times, likely a combined result of both 


\section{Light Demanding}

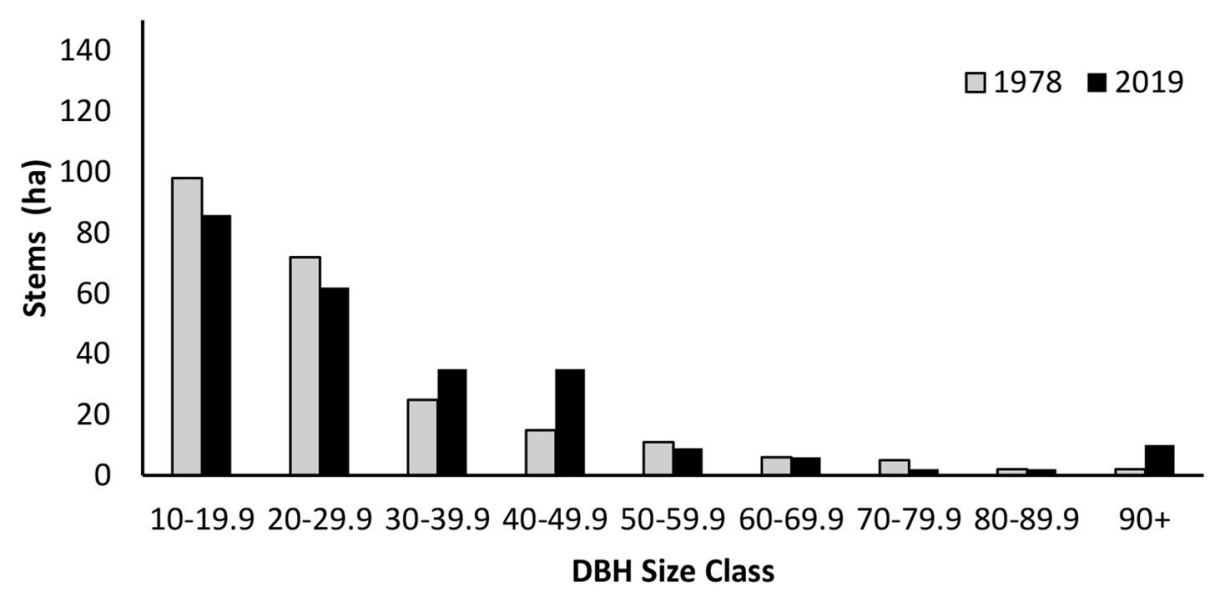

Shade Tolerant

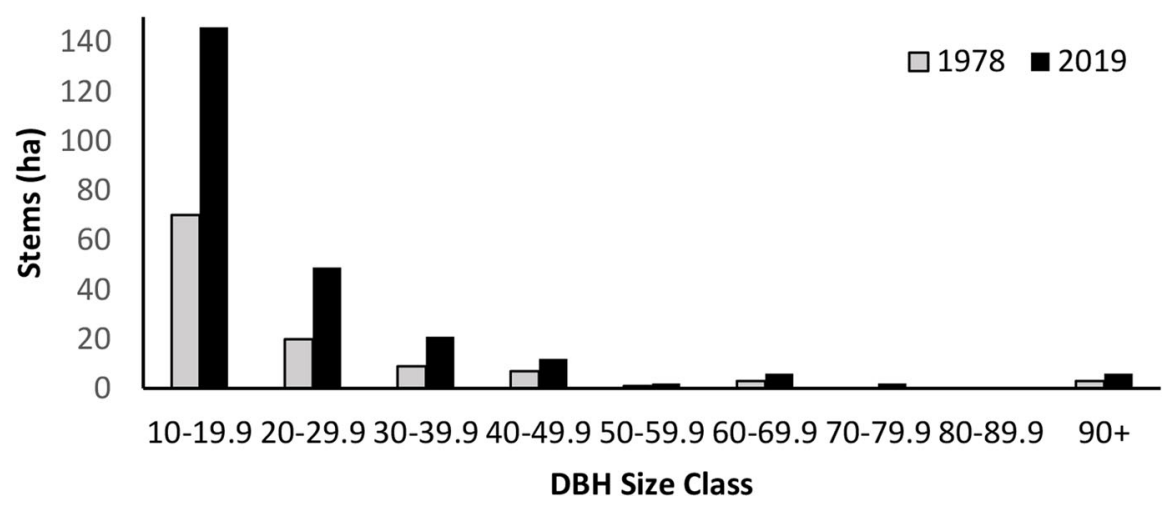

Fig. 3 The stand structure (plotted at $10 \mathrm{~cm}$ size class intervals) for light demanding and shade tolerant species. Sampling was conducted approximately 40 years apart (1978 and 2019) in an old-growth area of Kibale National Park, Uganda

births and immigration of forest elephants and effective recent anti-poaching efforts (Keigwin et al. 2016). However, hunting and habitat degradation dramatically impacted elephant populations in Uganda over the last 100 years. Brooks and Buss (1962) reported that the area used by elephants in Uganda was reduced by $75 \%$ between 1929 and 1959 partially in association with the 40,000 elephants killed by Ugandan control workers and trophy hunters. In the early $1960 \mathrm{~s}$, Kibale was thought to support 1,773 elephants (Wing and Buss 1970), in 1996 the population was estimated at 300 animals (Cochrane 2003), while in 2005 an extensive transect census of the park estimate the number of elephants to be 393 (95\% confidence limits 230-675, Wanyama et al. 2009). These studies indicate that elephant numbers have been reduced but are recovering. Elephants prefer the logged areas of Kibale where terrestrial vegetation is more abundant and our results suggest that given their current density, their trampling of seedlings and foraging has not impacted the old-growth forest (Lawes and Chapman 2006).

We found no evidence that observed increases in the abundance of frugivores led to an increase in the trees whose seeds they disperse. Similarly, despite five decades of observation to determine which tree species the folivorous primates damage and kill through overuse, only slightly more than half of the tree species examined followed the predicted pattern. For elephants, we found that only $33 \%$ of preferred tree species in the diet of elephants decreased in abundance. The effects of frugivory and herbivory do not appear to be strong enough to affect forest composition over the time period and spatial scale evaluated.

It is possible that other biotic factors obscured the effect of herbivory and frugivory. For example, the increase in the number of frugivores may have resulted in more seeds being dispersed, but seed predators increased during this same period, masking recruitment trends 
such as observed for Monodora myristica in Kibale (Balcomb and Chapman 2003). A site with greater frugivore density had more seeds dispersed, but this did not result in more saplings. Alternatively, it is possible that 40 years of monitoring is insufficient to detect change as tropical trees have slow growth. For example, Chrysophyllum sp. seedlings and saplings grow extremely slowly in the shaded understory, with their mean height doubling only every 27 years (Connell and Green 2000). Thus, a $20-\mathrm{cm}$ seedling could take almost 60 years to reach a meter in height, if it survived that long in the understory and did not have the growth advantage of a light gap (see also Kalbitzer et al. 2019). Clearly a longterm perspective is needed to examine the cascading effects of one change, such as the gradual decline in seed disperser abundance in a forest.

With respect to anthropogenic changes - century old human-induced disturbance and climate change - our findings are mixed. Forest disturbance that occurred prior to written history may still be affecting changes in the forest tree species composition, but no consistent pattern is revealed. As we expected (Prediction 3), lightdemanding species decreased in abundance over time, while the abundance of shade tolerant species increased. Presumably, the light demanding species became abundant in the forest following a historical disturbance and these trees are now senescing, dying, and not being replaced. However, we also predicted that species that typically recruit into large disturbed areas should decline between 1978 and 2019 and this was not supported by our data. We could not make a priori predictions of the effect of temperature change on specific tree species independently of changes in rainfall. Thus, we were unable to test how specific tree species were affected by the observed increase in temperature.

\section{Conclusions}

We present a 40-year record of change in a tropical tree community, and some of the longest and most detailed records of tropical forest mammal populations dynamics ever accumulated, and site-specific information on tree life-history strategies, climate change, and on forest disturbance that occurred prior to written history. With respect to primates and elephants, we have decades of observational data and ecological studies upon which to examine the influence of foraging on plant species sorting. Our study revealed subtle changes in the tree community between 1978 and 2019, sizable increases in primate numbers, and a substantial increase in the elephant population. Yet, a clear picture of what set of interactions impact the change in the tree community remains elusive. Our data on tree life-history strategies and frugivore/herbivore foraging preferences suggest that tree species are under opposing pressures. For example, both C. gomphophylla and D. abyssinica were predicted to decrease because they have been senescing after an anthropogenic disturbance 200-400 years ago. However, since the frugivores that disperse seeds of these tree species have increased in abundance, any influence from the prior anthropogenic disturbance may have been obscured.

Our exploration illustrates the challenges that must be faced to understand and predict change in terrestrial plant community dynamics. Of critical importance to addressing forest dynamics are long-term data and the interactions among important variables/processes over long time frames (Franklin et al. 2016). To understand the nature of these interactions, emphasis should be given to forests that have not recently experienced major disturbances, both in terms of the forest structure and animal populations. Disturbance to these interactors may have cascading effects on the forest community that take decades to return to a typical state - if there is a typical state at all (Pickett 1980). However, such studies can act as a comparison point to build a framework for future efforts. Within such a framework the scientific community can address whether and when forests will be influenced by altered biogeochemical conditions (e.g., $\mathrm{CO}_{2}$ enrichment or $\mathrm{N}$ deposition) and novel assemblages of plants and animals, including invasive species or where diseases or human actions cause dramatic declines in populations (Franklin et al. 2016). Given the current global conditions it will be important to explore how interactions between climate and disturbance regimes lead to shifts among vegetation types, with special attention given to thresholds. Modeling efforts will be required to integrate plant physiology, demography, and biogeography, past forest history, and future climate and land use change (Franklin et al. 2016). A significant challenge will be to predict how forest communities have been influenced by past human impacts and how they will respond to future policy changes. By meeting these challenges researchers will have the information to convince policy makers of the appropriate actions that must be taken to most effectively conserve the rich biodiversity of tropical forests.

\section{Supplementary Information}

The online version contains supplementary material available at https://doi. org/10.1186/s40663-021-00343-7.

\section{Additional file 1:}

\section{Acknowledgements}

We thank Peter Grubb for his help in assigning species to shade-tolerant or light-demanding niches and Joe Skorupa for conducting the primate census in the 1980 s. We particularly thank Thomas T. Struhsaker for his valuable help over the years, for providing the raw data for the early tree enumeration and primate census, and for helpful comments on the manuscript. 
Rafael Reyna-Hurtado provided helpful comments on this research and manuscript.

\section{Authors' contributions}

CC conceived of the research and initiated the project, CC, JFG, ML, AS, UK formalized the hypotheses, CC, PO collected the data, CC, CG-A, JFG, RH, ML, DS, AS, and UK analysed the data and all authors wrote the manuscript and approved the final version.

\section{Funding}

We would like to thank the Humboldt Foundation for providing the time to develop some of these ideas, the IDRC grant "Climate change and increasing human-wildlife conflict", National Science Foundation of China (No. 31,870,396), National Geographic, and the Leakey Foundation who helped fund the latest enumeration of the plots. JFG was supported by the Deutsche Forschungsgemeinschaft (DFG) Research Group "Sociality and Health in Primates" (FOR2136) and CG-A received a postdoctoral scholarship from DGAPA-UNAM

\section{Declarations}

\section{Ethics approval and consent to participate}

Not applicable.

\section{Consent for publication}

Not applicable.

\section{Competing interests}

The authors declare that they have no competing interests.

\section{Author details}

'Department of Anthropology, Center for the Advanced Study of Human Paleobiology, The George Washington University, 20037 Washington, DC, USA. ${ }^{2}$ Wilson Center, 1300 Pennsylvania Avenue NW, 20004 Washington, DC, USA. ${ }^{3}$ School of Life Sciences, University of KwaZulu-Natal, Scottsville, Pietermaritzburg, South Africa. ${ }^{4}$ Shaanxi Key Laboratory for Animal Conservation, Northwest University, Xi'an, China. ${ }^{5}$ Escuela Nacional de Estudios Superiores, Universidad Nacional Autónoma de México, Morelia, Michoacán, Mexico. ${ }^{6}$ Viral Evolution and Epidemiology of Highly Pathogenic Microorganisms, Robert Koch Institute, Seestraße 10, 13353 Berlin, Germany. ${ }^{7}$ Institute of Biodiversity and Environmental Conservation (IBEC), Universiti Malaysia Sarawak, 94300 Kota Samarahan, Sarawak, Malaysia. ${ }^{8}$ Makerere University Biological Field Station, Fort Portal, Uganda. ${ }^{9}$ Department of Geography and Environmental Studies, Carleton University, Ottawa, Canada. ${ }^{10}$ School of Life Sciences, Harold L. Lyon Arboretum, University of Hawai'i at Mānoa, 3190 Maile Way, 96822 Honolulu, HI, USA. "'Department for the Ecology of Animal Societies, Max Planck Institute of Animal Behavior, Radolfzell, Germany. ${ }^{12}$ Department of Biology, University of Konstanz, Konstanz, Germany.

\section{Received: 11 April 2021 Accepted: 10 July 2021}

\section{Published online: 09 October 2021}

\section{References}

Balcomb SR, Chapman CA (2003) Bridging the gap: Influence of seed deposition on seedling recruitment in a primate-tree interaction. Ecol Monogr 73:625-642

Bloor JM, Grubb PJ (2003) Growth and mortality in high and low light: trends among 15 shade-tolerant tropical rain forest tree species. J Ecol 91:77-85

Bradshaw CJ, Sodhi NS, Brook BW (2009) Tropical turmoil: a biodiversity tragedy in progress. Front Ecol Environ 7:79-87

Brooks AC, Buss IO (1962) Past and present status of the elephant in Uganda. J Wildl Manag 26:38-50

Brugiere D, Gautier J-P, Moungazi A, Gautier-Hion A (2002) Primate diet and biomass in relation to vegetation composition and fruiting phenology in a rain forest in Gabon. Int J Primatol 23:999-1023

Bush MB, Colinvaux PA (1994) Tropical forest disturbance: paleoecological records from Darien, Panama. Ecology 75:1761-1768

Bush MB, Silman MR, de Toledo MB, Listopad C, Gosling WE, Williams C, de Oliveira PE, Krisel C (2007) Holocene fire and occupation in Amazonia: records from two lake districts. Philos Trans R Soc Lond B Biol Sci 362:209218
Butynski TM (1990) Comparative ecology of blue monkeys (Cercopithecus mitis) in high- and low-density sub-populations. Ecol Monogr 60:1-26

Chao A, Chiu C-H, Hsieh T (2012) Proposing a resolution to debates on diversity partitioning. Ecology 93:2037-2051

Chapman CA (1995) Primate seed dispersal: coevolution and conservation implications. Evol Anthrop 4:74-82

Chapman CA, Chapman L (1997) Forest regeneration in logged and unlogged forests of Kibale National Park, Uganda. Biotropica 29:396-412

Chapman CA, Lambert JE (2000) Habitat alteration and the conservation of African primates: case study of Kibale National Park, Uganda. Am J Primatol 50:169-185

Chapman CA, Onderdonk DA (1998) Forests without primates: Primate/plant codependency. Am J Primatol 45:127-141

Chapman CA, Chapman LJ, Kaufman L, Zanne AE (1999) Potential causes of arrested succession in Kibale National Park, Uganda: growth and mortality of seedlings. Afr J Ecol 37:81-92

Chapman CA, Balcomb SR, Gillespie T, Skorupa J, Struhsaker TT (2000) Long-term effects of logging on African primate communities: A 28 year comparison from Kibale National Park, Uganda. Conserv Biol 14:207-217

Chapman CA, Chapman LJ, Gillespie TR (2002) Scale issues in the study of primate foraging: red colobus of Kibale National Park. Am J Phys Anthropol 117:349-363

Chapman CA, Chapman LJ, Vulinec K, Zanne A, Lawes MJ (2003) Fragmentation and alteration of seed dispersal processes: An initial evaluation of dung beetles, seed fate, and seedling diversity. Biotropica 35:382-393

Chapman CA, Chapman LJ, Struhsaker TT, Zanne AE, Clark CJ, Poulsen JR (2005) A long-term evaluation of fruiting phenology: importance of climate change. J Trop Ecol 21:31-45

Chapman CA, Struhsaker TT, Lambert JE (2005) Thirty years of research in Kibale National Park, Uganda, reveals a complex picture for conservation. Int J Primatol 26:539-555

Chapman CA, Kitajima K, Zanne AE, Kaufman LS, Lawes MJ (2008) A 10-yr evaluation of the functional basis for regeneration habitat preference of trees in an African evergreen forest. For Ecol Manage 225:3790-3796

Chapman CA, Chapman LJ, Jacob AL, Rothman JM, Omeja PA, Reyna-Hurtado R, Hartter J, Lawes MJ (2010a) Tropical tree community shifts: implications for wildlife conservation. Biol Conserv 143:366-374

Chapman CA, Struhsaker TT, Skorupa JP, Snaith TV, Rothman JM (2010b) Understanding long-term primate community dynamics: Implications of forest change. Ecol Appl 20:179-191

Chapman CA, Bonnell TR, Gogarten JF, Lambert JE, Omeja PA, Twinomugisha D, Wasserman MD, Rothman JM (2013a) Primates as ecosystem engineers. Int J Primatol 34:1-14

Chapman CA, Bonnell TR, Sengupta R, Goldberg TL, Rothman JM (2013b) Is Markhamia lutea's abundance determined by animal foraging? For Ecol Manage 308:62-66

Chapman CA, Bortolamiol S, Matsuda I, Omeja PA, Paim FP, Reyna-Hurtado R, Sengupta R, Valenta K (2018a) Primate population dynamics: variation in abundance over space and time. Biodivers Conserv 27:1221-1238

Chapman CA, Valenta K, Bonnell TR, Brown KA, Chapman LJ (2018b) Solar radiation and ENSO predict fruiting phenology patterns in a 16-year record from Kibale National Park, Uganda. Biotropica 50:384-395

Chave J, Coomes D, Jansen S, Lewis SL, Swenson NG, Zanne AE (2009) Towards a worldwide wood economics spectrum. Ecol Lett 12:351-366

Chazdon RL (2003) Tropical forest recovery: legacies of human impact and natural disturbances. Perspect Plant Ecol Evol Syst 6:51-71

Chesterman NS, Angedakin S, Mbabazi G, Tibisimwa J, Sandel AA (2019) Evidence and ecology of historic human settlements in Kibale National Park, Uganda. Hum Ecol 47:765-775

Clark DB (1996) Abolishing virginity. J Trop Ecol 12:735-739

Clutton-Brock T, Sheldon BC (2010) Individuals and populations: the role of longterm, individual-based studies of animals in ecology and evolutionary biology. Trend Ecol Evol 25:562-573

Cochrane EP (2003) The need to be eaten: Balanites wilsoniana with and without elephant seed-dispersal. J Trop Ecol 19:579-589

Coley P (1983) Herbivory and defensive characteristics of tree species in a lowland tropical forest. Ecol Monogr 53:209-233

Condit R, Pérez R, Lao S, Aguilar S, Hubbell SP (2017) Demographic trends and climate over 35 years in the Barro Colorado 50\&nbspiha plot. Forest Ecosyst 4:1-13

Connell JH, Green PT (2000) Seedling dynamics over thirty-two years in a tropical rain forest tree. Ecology 81:568-584 
Crawley MJ (1989) Insect herbivores and plant population dynamics. Ann Rev Entomol 34:531-562

Dalling JW, Schnitzer SA, Baldeck C, Harms KE, John R, Mangan SA, Lobo E, Yavitt JB, Hubbell SP (2012) Resource-based habitat associations in a neotropical liana community. J Ecol 100:1174-1182

Dublin HT, Sinclair ARE, McGlade J (1990) Elephants and fire as causes of multiple stable states in the Serengeti Mara woodlands. J Anim Ecol 59:1147-1164

Duncan RS, Chapman CA (2003) Consequences of plantation harvest during tropical forest restoration in Uganda. For Ecol Manag 173:235-250

Eggeling WJ, Dale IR (1952) The Indigenous Trees of the Uganda Protectorate. Government of Uganda Printer, Entebbe, Uganda

Fitter A, Fitter R (2002) Rapid changes in flowering time in British plants. Science 296:1689-1691

Franklin J, Serra-Diaz JM, Syphard AD, Regan HM (2016) Global change and terrestrial plant community dynamics. PNAS 113:3725-3734

Gautier-Hion A, Emmons LH, Dubost G (1980) A comparison of the diets of three major groups of primary consumers of Gabon (primates, squirrels and ruminants). Oecologia 45:182-189

Ghiglieri MP, Butynski TM, Struhsaker TT, Leland L (1982) Bush pig (Potamochoerus porcus) polychromatism and ecology in Kibale Forest, Uganda. Afr J Ecol 20:231-236

Gogarten JF, Jacob AL, Ghai RR, Rothman JM, Twinomugisha D, Wasserman MD, Chapman CA (2015) Group size dynamics over 15 + years in an African forest primate community. Biotropica 47:101-112

Gomez-Pompa A (1987) On Maya silviculture. University of California Press, Berkeley

Gotelli NJ, Chao A (2013) Measuring and estimating species richness, species diversity, and biotic similarity from sampling data. Encycl Biodiv 195-211

Griscom BW, Adams J, Ellis PW, Houghton RA, Lomax G, Miteva DA, Schlesinger WH, Shoch D, Siikamäki JV, Smith P (2017) Natural climate solutions. PNAS 114:11645-11650

Grubb PJ (1977) The maintenance of species-richness in plant communities: The importance of regeneration niche. Biol Rev 52:107-145

Gullison R, Panfil S, Strouse J, Hubbell S (1996) Ecology and management of mahogany (Swietenia macrophylla King) in the Chimanes Forest, Beni, Bolivia. Bot J Linn Soc 122:9-34

Hamilton AC (1974) Distribution patterns of forest trees in Uganda and their historical significance. Vegatatio 29:21-35

Hamilton AC (1984) Deforestation in Uganda. Oxford University Press, Oxford

Hamilton AC (1991) A field guide to Uganda forest trees. Makerere University Printery, Kampala

Hamilton AC, Taylor D, Vogel JC (1986) Early forest clearance and environmental degradation in south-west Uganda. Nature 320:164-167

Harris I, Osborn TJ, Jones P, Lister D (2020) Version 4 of the CRU TS monthly high-resolution gridded multivariate climate dataset. Sci Data 7:1-18

Harrison RD, Tan S, Plotkin JB, Slik F, Detto M, Brenes T, Itoh A, Davies SJ (2013) Consequences of defaunation for a tropical tree community. Ecol Lett 16:687-694

Hartell JA, Otali E, Machanda Z, Wrangham RW, Ross E (2020) Holistic approach for conservation of chimpanzees in Kibale National Park, Uganda. In: Hopper L, Ross S (eds) Chimpanzees in context: a comparative perspective on chimpanzee behavior, cognition, conservation, and welfare. University of Chicago Press, Chicago

Hladik CM (1977) A comparative study of the feeding strategies of two sympatric species of leaf monkeys: Presbytis senex and Presbytis entellus. In: CluttonBrock TH (ed) Primate ecology. Cambridge University Press, Cambridge, pp\&nbsp;324-353

Hou R, Reyna-Hurtado R, Omeja P, Tumwesigye C, Sarkar D, Gogarten JF, Chapman CA (2021) Long-term trends in a forest ungulate community: park establishment increases numbers, but poaching is a constant threat. Zool Res 42:201-211

Hsieh T, Ma K, Chao A (2013) iNEXT online: interpolation and extrapolation (Version 1.0)[Software]. http://chao.stat.nthu.edu.tw/blog/software-downlod. Accessed 02 Sep 2014

Hubbell SP, Foster RB, O'Brien ST, Harms KE, Condit R, Wechsler B, Wright SJ, Loode SL (1999) Light-gaps, disturbances, recruitment limitation, and tree diversity in a Neotropical forest. Science 283:554-557

Isabirye-Basuta GM, Lwanga JS (2008) Primate populations and their interactions with changing habitats. Int J Primatol 29:35-48

Jezkova T, Wiens JJ (2016) Rates of change in climatic niches in plant and animal populations are much slower than projected climate change. Proc R Soc B Biol Sci 283:20162104
Jin-Eong O (1995) The ecology of mangrove conservation and management. Hydrobiologia 295:343-351

Jost L (2006) Entropy and diversity. Oikos 113:363-375

Kalbitzer U, McInnis V, Chapman CA (2019) Primates create seedling growth hotspots through pattern of dung deposition. Afr J Ecol 57:190-197

Kasenene JM (1980) Plant regeneration and rodent populations in selectively felled and unfelled areas of Kibale Forest, Uganda. Masters, Makerere University

Kasenene JM (1984) The influence of selective logging on rodent populations and the regeneration of selected tree species in the Kibale Forest, Uganda. Trop Ecol 25:179-195

Kasenene JM (1987) The influence of mechanized selective logging, felling intensity, and gap-size on the regeneration of a tropical moist forest in the Kibale Forest Reserve, Uganda. Ph.D. Dissertation, Michigan State University

Katende A, Birnie A, Tengrias B (1995) Useful trees and shrubs for Uganda: Identification, propagation and management for agricultural and pastoral communities. Regional Soil Conservation Unit, Nairobi

Keigwin M, Wabukawo V, Wasser SK, Chapman CA (2016) Impacts on transboundary elephant movements between Queen Elizabeth National Park, Uganda and Park National des Virunga, Democratic Republic of Congo. Pachyderm 57:118-121

Kingston B (1967) Working plan for Kibale and Itwara Central Forest Reserves. Uganda Forest Department, Entebbe

Kitajima K, Poorter L (2008) Functional basis for resource niche partitioning by tropical trees. Trop Forest Comm Ecol 160-181

Lang Brown JR, Harrop JF (1962) The ecology and soils of the Kibale grasslands, Uganda. East Afr Agric For J 27:264-272

Langdale-Brown I, Osmaston HA, Wilson JG (1964) The vegetation of Uganda and its bearing to land-use. Ugandan Government Printer, Kampala

Lawes MJ, Chapman CA (2006) Does the herb Acanthus pubescens and / or elephants suppress tree regeneration in disturbed Afrotropical forests? For Ecol Manage 221:274-284

Laws RM (1970) Elephants as agents of habitat and landscape change in East Africa. Oikos 21:1-15

Lwanga JS (1994) The role of seed and seedling predators, and browsers on the regeneration of two forest canopy species Mimusops bagshawei and Strombosia scheffleri in Kibale Forest Reserve, Uganda. Ph.D. Dissertation, University of Florida

Lwanga JS (1996) Trees and shrubs. In: Howard PC, Davenport L, Matthews RA (eds) Kibale Forest biodiversity report. Forestry Department, Kampala, pp\&nbsp;5-36

Lwanga JS (2006) The influence of forest variation and possible effects of poaching on duiker abundance at Ngogo, Kibale National Park, Uganda. Afr J Ecol 44:209-218

Ma L, Lian J, Lin G, Cao H, Huang Z, Guan D (2016) Forest dynamics and its driving forces of sub-tropical forest in South China. Sci Rep 6:22561

Marcon E, Hérault B (2013) Entropart, an R package to partition diversity. R Foundation for Statistical Computing, Vienna

McCoy J (1995) Responses of blue and red duikers to logging in kibale forest western Uganda. Masters of Science, University of Florida

Mills DR, Do Linh San E, Robinson H, Isoke S, Slotow R, Hunter L (2019) Competition and specialization in an African forest carnivore community. Ecol Evol 9:10092-10108

Mitani JC, Struhsaker TT, Lwanga JS (2000) Primate community dynamics in old growth forest over 23.5 years at Ngogo, Kibale National Park, Uganda: Implications for conservation and census methods. Int J Primatol 21:269-286

Molloy L, Hart JA (2002) Duiker food selection: palatability trials using natural foods in the Ituri Forest, Democratic Republic of Congo. Zoo Biology: Published in affiliation with the American. Zoo Aquarium Association 21:149-159

Naughton-Treves L (1999) Whose animals? A history of property rights to wildlife in Toro, western Uganda. Land Degrad Develop 10:311-328

Nummelin M (1990) Relative habitat use of duikers, bush pigs, and elephants in virgin and selectively logged areas of the Kibale Forest, Uganda. Trop Zool 3: $111-120$

Oates JF (1977) The guereza and its food. Clutton-Brock TH (ed) Primate Ecology. Academic Press, New York, pp\&nbsp;275-321

Olupot W (1998) Long-term variation in mangabey (Cercocebus albigena johnstoni Lydekker) feeding in Kibale National Park, Uganda. Afr J Ecol 36:96-101

Omeja PA, Jacob AL, Lawes MJ, Lwanga JS, Rothman JM, Tumwesigye C, Chapman CA (2014) Changes in elephant density affect forest composition and regeneration? Biotropica 46:704-711 
Omeja PA, Lawes MJ, Corriveau A, Valenta K, Sarkar D, Paim FP, Chapman CA (2016) Recovery of tree and mammal communities during large-scale forest regeneration in Kibale National Park, Uganda. Biotropica 48:770-779

Osmaston HA (1959) Working plan for the Kibale and Itwara Forests. Ugandan Forest Department, Entebbe

Pacheco LF, Simonetti JA (2000) Genetic structure of a mimosoid tree deprived of its seed disperser, the spider monkey. Conserv Biol 14:1766-1775

Pickett ST (1980) Non-equilibrium coexistence of plants. Bull Torrey Bot Club 238-248

Polhill RM (1952) Flora of tropical East Africa. Balkema AA, Rotterdam

Poulsen JR, Clark CJ, Palmer TM (2013) Ecological erosion of an Afrotropical forest and potential consequences for tree recruitment and forest biomass. Biol Conserv 163:122-130

R-Core-Team (2020) R: A language and environment for statistical computing. R Foundation for Statistical Computing, Vienna

Richards PW (1996) The tropical rain forest, Second\&nbsp;edn. Cambridge University Press, Cambridge

Rode KD, Chapman CA, McDowell LR, Stickler C (2006) Nutritional correlates of population density across habitats and logging intensities in redtail monkeys (Cercopithecus ascanius). Biotropica 38:625-634

Rudran R (1978) Socioecology of the blue monkeys (Cercopithecus mitis stuh/manni) of the Kibale Forest, Uganda. Smiths Contrib Zool 249:1-88

Sæther B-E, Lande R, Engen S, Weimerskirch H, Lillegård M, Altwegg R, Becker PH, Bregnballe T, Brommer JE, McCleery RH (2005) Generation time and temporal scaling of bird population dynamics. Nature 436:99-102

Skorupa JP (1988) The effect of selective timber harvesting on rain forest primates in Kibale Forest, Uganda. PhD Dissertation, University of California, Davis

Skorupa JP, Kasenene JM (1984) Tropical forest management: can rates of natural treefalls help guide us? Oryx 18:96-101

Snook LK (1996) Catastrophic disturbance, logging and the ecology of mahogany (Swietenia macrophylla King): grounds for listing a major tropical timber species in CITES. Bot J Linn Soc 122:35-46

Stickler CM (2004) The effects of logging on primate-habitat interactions: A case study of redtail monkeys (Cercopithecus ascanius) in Kibale National Park, Uganda. M.Sc. Thesis, University of Florida, Gainesville, Florida

Struhsaker $\Pi$ (1975) The Red Colobus Monkey. University of Chicago Press, Chicago

Struhsaker $\Pi$ (1997) Ecology of an African rain forest: logging in Kibale and the conflict between conservation and exploitation. University of Florida Press, Gainesville

Struhsaker TT (2017) Dietary Variability in redtail monkeys (Cercopithecus ascanius schmidti) of Kibale National Park, Uganda: the role of time, space, and hybridization. Int J Primatol 38:914-941

Struhsaker T, Lwanga JS, Kasenene JM (1996) Elephants, selective logging, and forest regeneration in Kibale forest, Uganda. J Trop Ecol 12:45-64

Stuart NOE, Hatton JC, Spencer DHN (1985) The effect of long-term exclusion of large herbivores on vegetation in Murchison Falls National Park, Uganda. Biol Conserv 22:229-245

Swaine M, Lieberman D, Putz FE (1987) The dynamics of tree populations in tropical forest: a review. J Trop Ecol 3:359-366

Taylor D, Marchant RA, Robertshaw P (1999) A sediment-based history of medium altitude forest in central Africa: A record from Kabata Swamp, Ndale volcanic field, Uganda. J Ecol 87:303-315

Tutin CEG, Oslisly R (1995) Homo, Pan, and Gorilla: coexistence over 60,000 years at Lope in central Gabon. J Hum Evol 28:597-602

van Vliet A, Schwartz MD (2002) Phenology and climate: the timing of life cycle events as indicators of climate variability and change. Int J Clim 22:17131714

Walther GR, Post E, Convey P, Menzel A, Parmesan C, Beebee TJC, Fromentin JM, Hoegh-Guldberg O, Bairlein F (2002) Ecological responses to recent climate change. Nature 416:389-395

Wanyama F, Muhabwe R, Plumptre AJ, Chapman CA, Rothman JM (2009) Censusing large mammals in Kibale National Park: evaluation of the intensity of sampling required to determine change. Afr J Ecol 48:953-961

Weisse M, Gladman ED (2020) We lost a football pitch of primary rainforest every 6 seconds in 2019. World Resource Institute

Wing LD, Buss IO (1970) Elephants and forests. Wildlife Monographs 19

Wolkovich EM, Cook Bl, Allen JM, Crimmins TM, Betancourt JL, Travers SE, Pau S, Regetz J, Davies TJ, Kraft NJ (2012) Warming experiments underpredict plant phenological responses to climate change. Nature 485:494-497
Wolosin M, Harris N (2018) Tropical Forests and Climate Change: The Latest Science. World Resources Institute Washington DC

Wright SJ (2002) Plant diversity in tropical forests: a review of mechanisms of species coexistence. Oecologia 130:1-14

Wright S, Calderón O (2006) Seasonal, El Nino and longer term changes in flower and seed production in a moist tropical forest. Ecol Lett 9:35-44

Wright JP, Jones CG (2006) The concept of organisms as ecosystem engineers ten years on: progress, limitations, and challenges. Bioscience 56:203-209

Wright SJ, Stoner KE, Beckman N, Corlet RT, Dirzo R, Muller-Landau HC, NunesIturri G, Peres CA, Wang BC (2007) The plight of large animals in tropical forest and the consequences for plant regeneration. Biotropica 39:289-291

Zanne AE, Chapman CA (2005) Diversity of woody species in forest, treefall gaps, and edge in Kibale National Park, Uganda. Plant Ecol 178:121-139

Zanne AE, Keith B, Chapman CA, Chapman LJ (2001) Protecting terrestrial mammal communities: potential role of pine plantations. Afr J Ecol 39:399401

Zanne AE, Chapman CA, Kitajima K (2005) Evolutionary and ecological correlates of early seedling morphology in East African trees and shrubs. Am J Bot 92: 972-978

\section{Submit your manuscript to a SpringerOpen ${ }^{\circ}$ journal and benefit from:}

- Convenient online submission

- Rigorous peer review

- Open access: articles freely available online

- High visibility within the field

- Retaining the copyright to your article

Submit your next manuscript at $\boldsymbol{\nabla}$ springeropen.com 